Article

\title{
Gold Nanoparticle-Mediated Photoporation Enables Delivery of Macromolecules over a Wide Range of Molecular Weights in Human CD4+ T Cells
}

\author{
Laurens Raes ${ }^{1}$, Clarissa Van Hecke ${ }^{2}$, Julie Michiels ${ }^{1}$, Stephan Stremersch ${ }^{1}$, Juan C. Fraire ${ }^{1} \mathbb{D}$, \\ Toon Brans ${ }^{1}$, Ranhua Xiong ${ }^{1}$ (D), Stefaan De Smedt ${ }^{1}$, Linos Vandekerckhove ${ }^{2}$, \\ Koen Raemdonck ${ }^{1}$ and Kevin Braeckmans ${ }^{1, *(D)}$ \\ 1 Laboratory of General Biochemistry \& Physical Pharmacy, Ghent University, Ottergemsesteenweg 460, \\ 9000 Ghent, Belgium \\ 2 HIV Cure Research Center, Department of Internal Medicine, Ghent University, Corneel Heymanslaan 10, \\ 9000 Ghent, Belgium \\ * Correspondence: Kevin.Braeckmans@ugent.be; Tel.: +32-9-2648098; Fax: +32-9-2648189
}

Received: 17 June 2019; Accepted: 5 August 2019; Published: 7 August 2019

\begin{abstract}
The modification of CD4+ T cells with exogenous nucleic acids or proteins is a critical step in several research and therapeutic applications, such as HIV studies and cancer immunotherapies. However, efficient cell transfections are not always easily achieved when working with these primary hard-to-transfect cells. While the modification of $\mathrm{T}$ cells is typically performed by viral transduction or electroporation, their use is associated with safety issues or cytotoxicity. Vapor nanobubble (VNB) photoporation with sensitizing gold nanoparticles (AuNPs) has recently emerged as a new technology for safe and flexible cell transfections. In this work, we evaluated the potential of VNB photoporation as a novel technique for the intracellular delivery of macromolecules in primary human CD4+ T cells using fluorescent dextrans as model molecules. Our results show that VNB photoporation enables efficient delivery of fluorescent dextrans of $10 \mathrm{kDa}$ in Jurkat ( $>60 \% \mathrm{FD} 10+$ cells) as well as in primary human CD4+ T cells $( \pm 40 \%$ FD10 + cells), with limited cell toxicity ( $>70 \%$ cell viability). We also demonstrated that the technique allows the delivery of dextrans that are up to $500 \mathrm{kDa}$ in Jurkat cells, suggesting its applicability for the delivery of biological macromolecules with a wide range of molecular weights. Altogether, VNB photoporation represents a promising technique for the universal delivery of macromolecules in view of engineering $\mathrm{CD} 4+\mathrm{T}$ cells for use in a wide variety of research and therapeutic applications.
\end{abstract}

Keywords: gold nanoparticles; vapor nanobubble; photoporation; T cells; intracellular delivery; macromolecules

\section{Introduction}

Adoptive $\mathrm{T}$ cell transfer represents a promising, emerging approach for cancer immunotherapy and HIV therapy [1]. The generation of adoptive T cells, such as chimeric antigen receptor (CAR) $\mathrm{T}$ cells, requires genetic engineering to make the cells more potent to recognize and kill tumor cells or HIV-infected cells [2-4]. Although CD8+ cytotoxic T lymphocytes (CTLs) are preferred for tumor targeting, CD4+ 'helper' T cells support and enhance CTL activity, and are therefore essential to create an efficacious antitumor environment $[5,6]$. Furthermore, the use of genetically modified CD4+ T cells is thoroughly investigated for different treatment modes of HIV-infected patients, including the adoptive transfer of CCR5-modified CD4+ T cells [7-11].

For the generation of adoptive CD4+ T cells, the efficient intracellular delivery of genes (e.g. coding for CAR) or proteins (e.g. CRISPR/Cas9) is indispensable [12]. Indeed, the therapeutic benefit of CD4+ T 
cells for some promising cancer immunotherapies [5] and functional cures for HIV infection [13] strongly relies on the efficient modification of their functionality. However, current delivery technologies for these hard-to-transfect $\mathrm{T}$ cells are associated with various limitations [14-16]. Viral vectors typically yield high transduction efficiencies, but their use is expensive, labor-intensive, and associated with significant safety issues $[17,18]$. While lipid-based and polymer-based nanoparticles can be safer alternatives, efficient transfection is often hindered by poor uptake, e.g., in blood and immune cells [14], limited endosomal escape $[19,20]$, and delayed unpacking of the cargo molecules from the carriers in the cytosol [21]. In addition, these synthetic carriers can typically only be used with specific cargo molecules (e.g., nucleic acids) and cell types [22].

In view of the limitations associated with viral and non-viral carriers, membrane-permeabilization methods have received increasing attention for the transfection of cells in vitro or ex vivo, owing to their ability to deliver a broad variety of cargoes into a wide range of cell types [15,22]. Electroporation is frequently used for the in vitro or ex vivo delivery of different types of macromolecules [23,24]. However, high electric fields can result in a drastic decrease in cell viability; also, electroporation has been shown to substantially alter the $T$ cell phenotype and reduce its therapeutic efficacy $[25,26]$. More recently, microfluidics approaches for transient mechanical membrane poration by cell squeezing were shown to enable the transfection of different cell types with limited cytotoxicity $[27,28]$. However, a practical limitation is that typically a new dedicated microfluidic chip needs to be developed for each cell type, as there is a strong correlation between cell size and transfection efficiency [22]. An emerging alternative transfection technology that offers wide applicability with limited cytotoxicity is vapor nanobubble (VNB) photoporation (Figure 1).

(a)

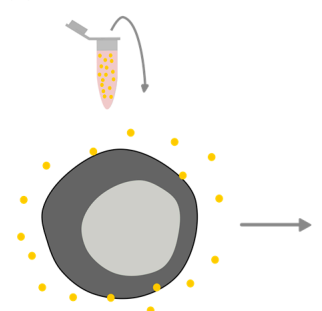

AuNP attachment (b)

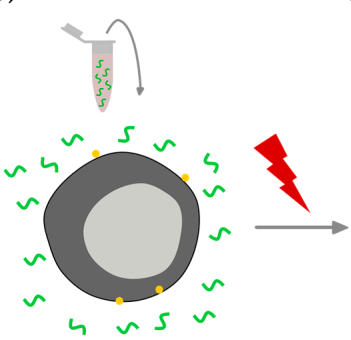

Addition of macromolecules (c)

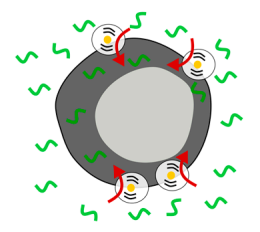

Laser-assisted VNB formation

\& delivery of macromolecules

Figure 1. Vapor nanobubble (VNB) photoporation procedure for delivery of macromolecules in T cells. (a) First, cationic plasmonic gold nanoparticles (AuNPs) are incubated with the cells, allowing them to adsorb to the negatively charged cell membrane. (b) Next, the macromolecules of interest are added to cells. (c) Upon nanosecond pulsed laser irradiation, VNBs arise from the cell-bound AuNPs. After all the thermal energy is consumed, the VNBs will collapse and the associated shock waves cause physical cell membrane poration. This allows the extracellular macromolecules to diffuse into the cell cytoplasm.

The technique typically makes use of plasmonic gold nanoparticles (AuNPs), which absorb laser light and efficiently convert it into thermal energy $[29,30]$. When absorbing intense nanosecond or picosecond laser pulses, AuNPs are heated to high temperatures and cause an almost instantaneous evaporation of the water layer in contact with the AuNP surface. This in turn leads to the formation of water vapor nanobubbles (VNB) that emerge around these particles upon the absorption of a laser pulse. The VNB will expand up to several hundred nm until the thermal energy from the AuNP is consumed, after which the bubble violently collapses, producing pressure waves that can cause mechanical damage to neighboring structures, such as a cell membrane. The disruptive mechanical force of these VNBs can thus be used for efficient pore formation in cell membranes, allowing the intracellular delivery of biological macromolecules [31-33]. The applicability of the technique for the transfection of different macromolecules in various cell types has been amply demonstrated, including siRNA in adherent tumor cells [34] and murine CD8+ T cells [35]. 
Based on the promising results obtained with murine T cells, we here explored the suitability of VNB photoporation for the intracellular delivery of macromolecules in human CD4+ T cells, using fluorescent dextrans as model molecules. Previous studies from our group already indicated that a good correlation is obtained in delivery efficiency for fluorescent dextrans and functional macromolecules, such as siRNA [34,35], motivating their use as model macromolecules. In-house synthetized AuNPs were first extensively characterized to ensure reproducible cell attachment and the generation of VNBs. Next, the VNB photoporation procedure was successfully optimized for the delivery of $10 \mathrm{kDa}$ fluorescent dextrans (FD10) in Jurkat cells and primary human CD4+ T cells. We showed that by screening for different AuNP concentrations, VNB photoporation conditions were found that enable efficient delivery in $>60 \%$ of Jurkat cells and in up to $40 \%$ of primary CD4+ T cells, while maintaining high cell viability $(>70 \%)$. To demonstrate that VNB photoporation can be used to deliver even larger compounds, Jurkat cells were furthermore photoporated in the presence of dextrans up to $500 \mathrm{kDa}$ (FD500), resulting in over 50\% FD500-positive cells. In conclusion, these results demonstrate the potential of VNB photoporation for the efficient intracellular delivery of macromolecules in primary human $\mathrm{CD} 4+\mathrm{T}$ cells, thereby providing a very promising basis for future research on the transfection of functional macromolecules in view of CD4+ T-cell engineering.

\section{Materials and Methods}

\subsection{Synthesis and Characterization of $60 \mathrm{~nm}$ AuNPs}

The synthesis of AuNPs with a core size of $60 \mathrm{~nm}$ was performed by a two-step procedure, using the Turkevich method [36,37]. First, AuNP seeds were formed by adding $0.01 \mathrm{M}$ of citrate solution (Sigma-Aldrich, Bornem, Belgium) to $0.2 \mathrm{mM}$ of chloroauric acid $\left(\mathrm{HAuCl}_{4}\right.$; Sigma-Aldrich, Bornem, Belgium) solution under rapid stirring and allowing this mixture to react for $30 \mathrm{~min}$. Next, larger AuNPs were obtained by overgrowing these AuNP seeds by adding $\mathrm{Au}^{3+}$ ions and ascorbate solution at an equimolar concentration of $0.01 \mathrm{M}$. The dipolar localized surface plasmon resonance (LSPR) peak of the UV-VIS spectrum was controlled throughout this procedure by UV-VIS spectroscopy using a NanoDrop 2000c spectrophotometer (ThermoFisher, Rockford, IL, USA). The AuNP synthesis was stopped when the dipolar LSPR peak reached 536 to $545 \mathrm{~nm}$, corresponding to an average diameter of $60 \mathrm{~nm}$.

After synthesis, the AuNPs were made cationic by functionalization with poly (diallyldimethylammonium chloride) solution (PDDAC; Sigma-Aldrich, Bornem, Belgium). A final concentration of $0.06 \mathrm{mg} / \mathrm{mL}$ of PDDAC was used, and the mixture was allowed to react overnight. To remove unattached PDDAC, the AuNPs were washed by centrifugation $(5000 \times g, 10 \mathrm{~min})$ and eventually diluted in $\mathrm{ddH}_{2} \mathrm{O}$ to a stock concentration of $\sim 4 \times 10^{10} \mathrm{AuNPs} / \mathrm{mL}$.

The resulting AuNPs were characterized using a combination of dynamic light scattering, UV-VIS spectroscopy, electrodynamic modeling using the Mie theory, and transmission electron microscopy (TEM). For determination of the average zeta potential and hydrodynamic size, the initial AuNP stock was diluted $5 \times$ or $10 \times$ in $\mathrm{ddH}_{2} \mathrm{O}$, transferred to a folded capillary Zetasizer cell (Malvern, Worcestershire, UK), and measured with the Zetasizer Nano ZS (Malvern, Worcestershire, UK) equipped with Dispersion Technology Software (DTS). By recording the AuNP extinction spectrum, the AuNP core size and concentration were estimated. Using the extinction of the AuNP solution $(\varepsilon)$, which was measured at the maximal extinction wavelength, the AuNP concentration was estimated as follows in Equation (1) [38]:

$$
[A u N P]\left(\frac{\text { number of particles }}{m L}\right)=\varepsilon /\left(b \times \sigma_{\varepsilon}\right)
$$

where ' $\mathrm{b}$ ' is the optical path length $(1 \mathrm{~cm})$ and ' $\sigma_{\mathcal{\varepsilon}}{ }^{\prime}\left(1.4044 \times 10^{-10} \mathrm{~cm}^{2}\right.$ at $\left.538 \mathrm{~nm}\right)$ is the theoretical extinction cross-section for spherical particles, as calculated by the Mie theory [39]. Before every photoporation experiment, the zeta potential and UV-VIS spectrum of the AuNPs was measured. A zeta potential value of at least $+30 \mathrm{mV}$ was considered acceptable to ensure reproducible AuNP attachment to the cells. 
The stability of AuNPs in cell culture medium was analyzed by nanoparticle tracking analysis using a NanoSight LM10 instrument (Malvern, Worcestershire, UK). Prior to analysis, the AuNP stock was diluted $2000 \times$ in $\mathrm{ddH}_{2} \mathrm{O}$ or Jurkat culture medium, and injected into the sample chamber. Five movies of 60 seconds ( 25 frames/second) were recorded for each sample, performed in triplicate for each condition, and analyzed with the NTA Analytical Software version 2.3 (Malvern, Worcestershire, UK) to determine the mean hydrodynamic size (in nm) of the AuNPs in either cell culture medium or $\mathrm{ddH}_{2} \mathrm{O}$.

To verify the core size of the AuNPs, transmission electron microscopy (TEM) images were captured using a JEM 1400 plus transmission electron microscope (JEOL, Tokyo, Japan) at a voltage of $80 \mathrm{kV}$ (VIB-UGent Transmission Electron Microscopy-Core facility). For preparation of the samples, one drop $(\sim 25 \mu \mathrm{L})$ of the AuNP stock was applied onto a formvar/C-coated hexagonal copper grid (EMS G200H-Cu), incubated for $20 \mathrm{~min}$, and washed five times in $\mathrm{dd}_{2} \mathrm{O}$. Using the ImageJ software (FIJI, https://fiji.sc/), the AuNP core size distribution was determined.

\subsection{Detection of VNBs and Determination of VNB Generation Threshold}

For the generation and detection of VNBs, a homemade setup was used as previously described by Xiong et al. 2014 [34]. A pulsed laser, tuned at a wavelength of $561 \mathrm{~nm}$ (Opolette ${ }^{\mathrm{TM}} \mathrm{HE} 355 \mathrm{LD}$, OPOTEK Inc, Carlsbad, CA, USA), with a pulse duration of $7 \mathrm{~ns}$ and a laser pulse frequency of $20 \mathrm{~Hz}$, was used to illuminate the AuNPs for the generation of VNBs. Due to the short lifetime of VNBs, an electronic pulse generator (BNC575, Berkeley Nucleonics Corporation, San Rafael, CA, USA) was used to synchronize the camera (EMCCD camera, Cascade II: 512, Photometrics, Tucson, AZ, USA) with the pulsed laser. By this means, dark-field images were recorded before, during, and after VNB formation upon the absorption of a single laser pulse. The energy of the laser pulses was measured by an energy meter (LE, Energy Max-USB/RS sensors, Coherent, Santa Clara, CA, USA). The stock of $60 \mathrm{~nm}$ AuNPs $\left(\sim 4 \times 10^{10} \mathrm{AuNPs} / \mathrm{mL}\right)$ was diluted $50 \times$ in $\mathrm{ddH}_{2} \mathrm{O}$, and the dilution was transferred to $50 \mathrm{~mm} \gamma$-irradiated glass-bottom dishes (MatTek Corporation, Ashland, MA, USA). AuNPs were allowed to sediment on the bottom of the dish and were subsequently imaged by dark-field microscopy. The generated VNBs were visible as bright dots on a black background as a result of light scattering. For determination of the VNB generation threshold, the number of visible VNBs within the laser irradiated region $(150 \mu \mathrm{m}$ diameter) was quantified for increasing laser pulse fluences. The VNB threshold, which was defined as the laser fluence for which $90 \%$ of the maximal number of VNBs is obtained, was determined using a Boltzmann fit of the number of VNBs in the function of laser pulse fluence. All the further experiments were performed at approximately twice the VNB threshold value to ensure effective VNB formation.

\subsection{Jurkat and Primary Human CD4+ T Cell Culture}

Jurkat cells (human T cell leukemia line) were obtained from the American Type Culture Collection (ATCC ${ }^{\circledR}$ TIB-152 ${ }^{\mathrm{TM}}$ ). The cells were cultured in Roswell Park Memorial Institute (RPMI) 1640 medium supplemented with $10 \%$ fetal bovine serum, $2 \mathrm{mM} \mathrm{L}$-Glutamine and $100 \mu \mathrm{g} / \mathrm{mL}$ penicillin/streptomycin (GibcoBRL, Merelbeke, Belgium). The cells were maintained in a humidified atmosphere of $5 \% \mathrm{CO}_{2}$ at $37^{\circ} \mathrm{C}$, and the culture medium was renewed every 2 to 3 days.

One day prior to VNB photoporation, primary CD4+ T cells were isolated from buffy coats of healthy donors, which were donated after informed consent (Red Cross, Ghent, Belgium). Briefly, peripheral blood mononuclear cells (PBMCs) were isolated using density gradient centrifugation with Lymphoprep (ELITech Group, Belgium), and subsequently used for CD4+ T cell isolation by negative selection (EasySep, Stemcell technologies, Canada) according to manufacturer's protocol. Primary $\mathrm{CD} 4+\mathrm{T}$ cells were kept in culture at $37^{\circ} \mathrm{C}$ in a $5 \% \mathrm{CO}_{2}$ atmosphere in complete RPMI medium 1640, as described above for Jurkat cells, supplemented with 50 U/ml IL-2 (PeproTech, United Kingdom). 


\subsection{Visualization of AuNP Attachment and Quantification of the Number of AuNPs Per Cell}

Jurkat $\left(250 \times 10^{3}\right.$ cells $)$ or primary human CD4+ T cells $\left(1 \times 10^{6}\right.$ cells $)$ were incubated at $37^{\circ} \mathrm{C}$ for 30 min with different concentrations of AuNPs. Unbound AuNPs were removed by a washing step via centrifugation $(300 \times g, 5 \mathrm{~min})$ and resuspended in culture medium. Subsequently, a part of the cells $\left(50-250 \times 10^{3}\right.$ cells) was transferred to a glass-bottom 96-well plate (Greiner Bio-one, Frickenhausen, Germany). Visualization of the AuNP attachment to cells was performed using confocal reflection microscopy (C1si or C2, Nikon Benelux, Brussels, Belgium) with a $60 \times$ water immersion lens (Plan Apo 60x, NA 1.2, Nikon Benelux, Brussels, Belgium). AuNP scattering was obtained using a $560 \mathrm{~nm}$ diode laser (CVI Melles Grio, NM, USA). For visualization of the cell membrane and nucleus, CellMask Deep red membrane stain (Invitrogen, Waltham, USA) and Hoechst33342 (Invitrogen, Waltham, USA) were used, respectively. Both stains were diluted $1000 \times$ in culture medium, added to the cells, and incubated for $10 \mathrm{~min}$ at $37^{\circ} \mathrm{C}$. The cells were washed with culture medium and imaged using confocal (reflection) microscopy. Image processing included merging the different fluorescent or reflection images into a composite, using the ImageJ (FIJI) software.

\subsection{Delivery of FITC-Dextrans to Jurkat and Human CD4+ T Cells by VNB Photoporation}

For intracellular delivery of FITC-dextrans in Jurkat and primary human CD4+ T cells, the same protocol was used. The cells were first incubated with AuNPs, as described above, after which the unbound AuNPs were removed by washing with culture medium. After centrifugation ( $5 \mathrm{~min}, 300 \times g)$, the cells were resuspended in culture medium containing FITC-labeled dextrans (Sigma-Aldrich, Bornem, Belgium) of $10 \mathrm{kDa}$ (FD10), $150 \mathrm{kDa}$ (FD150), or $500 \mathrm{kDa}$ (FD500) at a final concentration of $2 \mathrm{mg} / \mathrm{mL}$. As the manufacturer states that all the FITC-dextrans are conjungated with a frequency of 0.003 to 0.020 mol FITC per mol of glucose, an equal mass concentration implies equal fluorescence. After transfer to a 96-well plate, the cells were treated by pulsed laser illumination $\left(I=1.9 \mathrm{~J} / \mathrm{cm}^{2}\right)$ for the generation of VNBs and the intracellular delivery of FITC-dextrans. Immediately after laser treatment, cells were washed twice by centrifugation $(300 \times g, 5 \mathrm{~min})$, and resuspended in culture medium. The cells were incubated at $37^{\circ} \mathrm{C}, 5 \% \mathrm{CO}_{2}$ for at least $2 \mathrm{~h}$ prior to analysis of the percentage of FITC-dextran positive cells or cell viability.

\subsection{Evaluation of FITC-Dextran Delivery by Confocal Microscopy and Flow Cytometry}

FITC-dextran uptake was visualized by confocal microscopy (C1si, Nikon Benelux, Brussels, Belgium) using a $10 \times$ objective lens (Plan Apo, NA 0.45, Nikon Benelux, Brussels, Belgium). The FITC label, which was attached to the dextran chains, was excited using a $488 \mathrm{~nm}$ argon-ion laser (CVI Melles Grio, NM, USA). For quantification of the percentage of FITC-dextran positive cells, the cells were measured by flow cytometry using a CytoFlex (Beckman Coulter, Suarlée, Belgium) flow cytometer. At least 10,000 single cells were gated for each sample. Flow cytometry data were analyzed using FlowJo (Treestar Inc., Ashland, OR, USA) software.

\subsection{Cell Viability Assay}

The viability of Jurkat cells and primary human $\mathrm{T}$ cells was assessed two hours after VNB photoporation treatment using a CellTiter-Glo ${ }^{\circledR}$ luminescent cell viability assay (Promega, Leiden, The Netherlands), according to the manufacturer's protocol. In short, 20 to $50 \mu \mathrm{L}$ of the cells per well was transferred to an opaque 96-well plate, and an equal volume CellTiter-Glo ${ }^{\circledR}$ reagent was added to each well. The content of the plate was mixed for 5 to $10 \mathrm{~min}$ using an orbital shaker (100 rpm), after which the luminescent signal was allowed to stabilize for $10 \mathrm{~min}$. The luminescent signal of each well was measured using a GloMax ${ }^{\text {TM }} 96$ luminometer (Promega, Leiden, The Netherlands). Cell viability for the different conditions was determined relatively compared to the untreated samples. 


\subsection{Statistical Analysis}

Data are given as mean value \pm standard deviation (SD). Graphpad Prism 8 (La Jolla, CA, USA) software was used to perform all the statistical analyses. Differences with a $p$-value $<0.05$ were considered significant.

\section{Results}

\subsection{Physicochemical Characterization of $60 \mathrm{~nm}$ Cationic AuNPs}

Cationic plasmonic gold nanoparticles (AuNPs) with a core size of about $60 \mathrm{~nm}$ and coated with poly(diallyldimethylammonium chloride) (PDDAC) were used as photothermal sensitizers for forming membrane pores. The synthesis of these AuNPs was performed by the production of AuNP seeds, followed by overgrowing these seeds to the desired size and functionalization with the cationic polymer PDDAC. By UV-VIS spectroscopy, it was found that the AuNP extinction spectrum matched well with that of $60 \mathrm{~nm}$ AuNPs (Figure 2a), as calculated from Mie theory. This result was further confirmed by transmission electron microscopy (TEM) imaging of the AuNPs, finding an average core diameter of $58 \pm 14 \mathrm{~nm}$ (Figure 2b,c). The AuNP hydrodynamic size and zeta potential was measured by dynamic light scattering (DLS) as well. A representative size and zeta potential distribution of the AuNPs are displayed in Figure 2d,e, respectively. The AuNPs were found to have an intensity mean size of $113 \pm 4 \mathrm{~nm}$ with a mean zeta potential of $+42 \pm 2 \mathrm{mV}$. The colloidal stability of AuNPs was additionally measured in cell culture medium by nanoparticle tracking analysis (Figure $2 \mathrm{f}$ ). AuNPs were diluted in either $\mathrm{ddH}_{2} \mathrm{O}$ or cell culture medium, and their hydrodynamic size was determined. The mean hydrodynamic size of AuNPs diluted in culture medium (127 $\pm 8 \mathrm{~nm})$ was found to be slightly, but significantly larger compared to the size of AuNPs in $\mathrm{ddH}_{2} \mathrm{O}(112 \pm 21 \mathrm{~nm})$, which may be due to the formation of a protein corona. Importantly, the hydrodynamic size of AuNPs in culture medium was very uniform with no signs of aggregation.

(a)

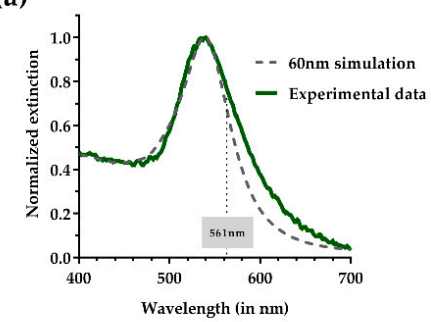

(d)

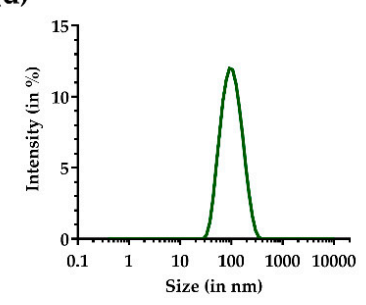

(b)

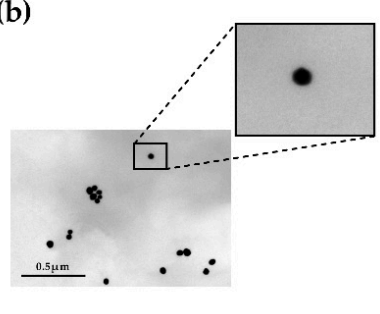

(e)

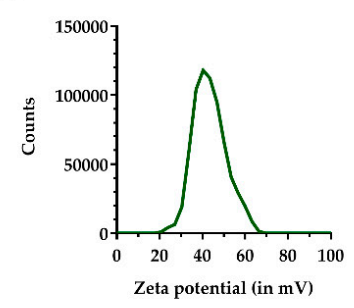

(c)

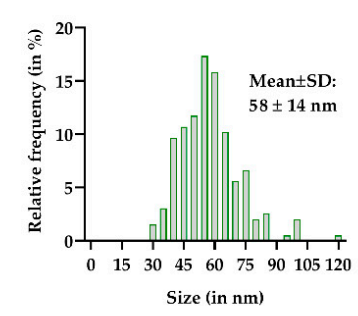

(f)

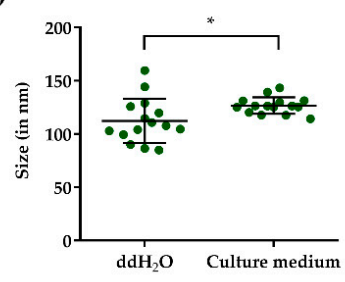

Figure 2. Characterization of $60 \mathrm{~nm}$ cationic AuNPs. (a) Normalized extinction spectrum of the synthetized AuNPs. The green line shows representative experimental data, as determined by UV-VIS spectroscopy. The dashed grey line shows the simulated extinction spectrum of $60 \mathrm{~nm}$ AuNPs, as determined by the Mie theory. (b) Representative transmission electron microscopy (TEM) image of the AuNPs (scale bar $=0.5 \mu \mathrm{m}$ ). (c) AuNP size distribution, as derived from the TEM images. Representative size (d) and zeta potential (e) distribution of the AuNPs (in $\mathrm{ddH}_{2} \mathrm{O}$ ) as determined by dynamic light scattering. (f) Stability of the AuNPs in $\mathrm{ddH}_{2} \mathrm{O}$ versus cell culture medium was determined by nanoparticle tracking analysis. The black lines represent the mean size $\pm \operatorname{SD}(n=3,5$ technical replicates each). A two-tailed unpaired student's $\mathrm{T}$ test was performed to determine statistical differences $\left({ }^{*} p<0.05\right)$. 


\subsection{Determination of the VNB Generation Threshold}

Illumination of plasmonic AuNPs with a nanosecond pulsed laser will cause the AuNP to be heated, eventually leading to the formation of VNBs as the laser fluence (energy per unit area) increases [33,34]. VNB can be visualized by dark field microscopy as they increase the amount of light scattering during their lifetime. This is illustrated in the dark field image sequence in Figure 3a. Before application of the laser pulse, AuNPs are visible as small diffraction limited spots of light. Immediately after the application of a single laser pulse within the indicated circle, VNBs are visible as short-lived intense flashes of light, as indicated by the yellow arrowheads. After that, almost no visible particles remain in the irradiated area since AuNPs tend to fragment upon pulsed laser irradiation [40]. By counting the number of VNBs within the irradiated area as a function of the laser pulse fluence, the so-called VNB generation threshold can be determined, which is defined as the laser fluence at which $90 \%$ of the maximal number of VNBs is obtained. From the data in Figure 3b, the threshold laser fluence was determined to be $0.96 \mathrm{~J} / \mathrm{cm}^{2}$. To assure effective VNB generation and subsequent membrane poration, a laser fluence of $1.9 \mathrm{~J} / \mathrm{cm}^{2}$, i.e., about twice the VNB threshold fluence, was chosen for subsequent VNB photoporation experiments.

(a)
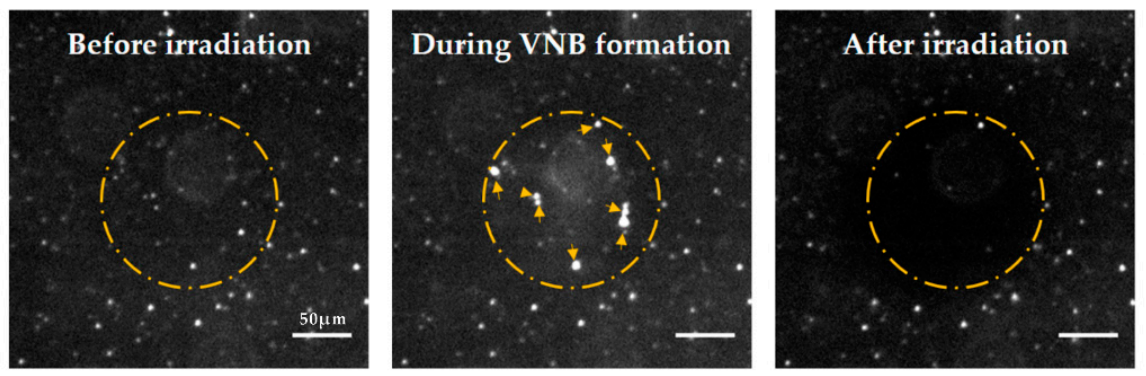

(b)

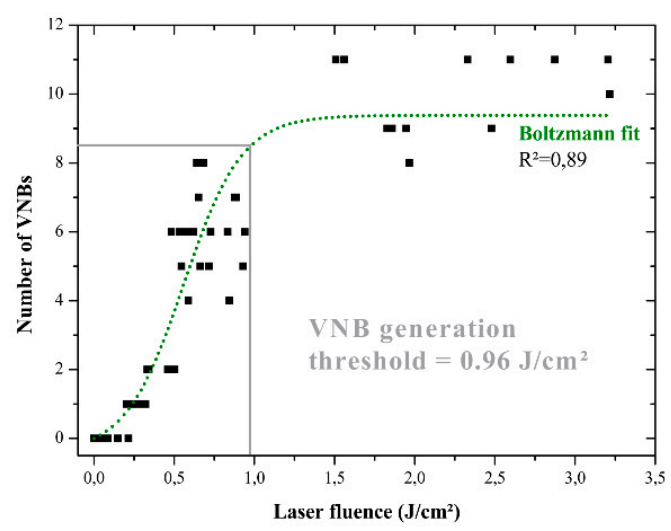

Figure 3. Determination of VNB generation threshold for $60 \mathrm{~nm}$ AuNPs by dark-field microscopy. (a) Detection of VNBs arising from $60 \mathrm{~nm}$ AuNPs (in $\mathrm{ddH}_{2} \mathrm{O}$ ) by dark field microscopy. The yellow dashed circle indicates the illuminated region with a diameter of $150 \mu \mathrm{m}$. Upon laser illumination $\left(\mathrm{I}=1.97 \mathrm{~J} / \mathrm{cm}^{2}\right)$, different VNBs can be observed as bright white spots that are indicated with yellow arrowheads (scale bar $=50 \mu \mathrm{m}$ ). (b) For determination of the VNB threshold, the number of bubbles was determined for increasing laser pulse fluences. The VNB threshold, which is defined as the laser pulse fluence at $90 \%$ of the asymptotic value of the Boltzmann fit, is indicated with the grey line.

\subsection{Visualization and Quantification of AuNP Attachment to Jurkat and Primary Human CD4+T Cells}

The initial step in the VNB photoporation procedure consists of incubating cells with cationic AuNPs that will adsorb electrostatically to the negatively charged cell membrane, allowing them to induce membrane pores upon laser irradiation and VNB generation. Based on the light scattering 
properties of AuNPs, the attachment of AuNPs to Jurkat and primary human T cells was visualized and subsequently quantified by confocal reflection microscopy. AuNPs were present on the cell membrane of both Jurkat (Figure 4a) and primary human T cells (Figure 4b). The number of cell-attached AuNPs increases for increasing concentrations of AuNPs, typically ranging from one to six AuNPs/cell. This trend was observed for both Jurkat (Figure 4c) and primary human T cells (Figure 4d), although substantially higher AuNP concentrations were necessary to obtain the same amount of cell-attached AuNPs for primary human T cells as compared to Jurkat cells.

\section{Jurkat}

(a)

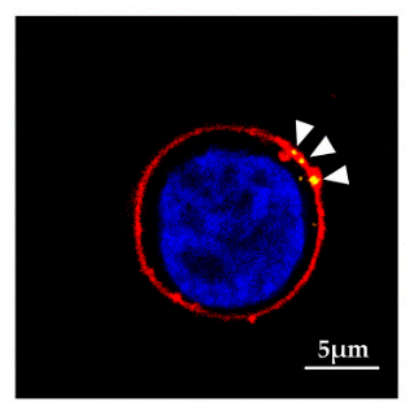

(c)

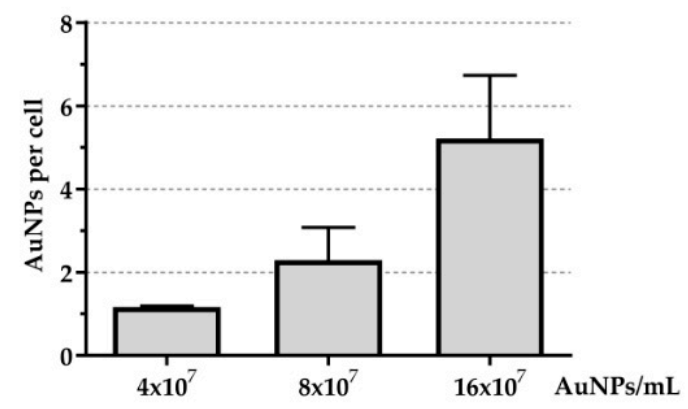

\section{Primary CD4+ T cell}

(b)

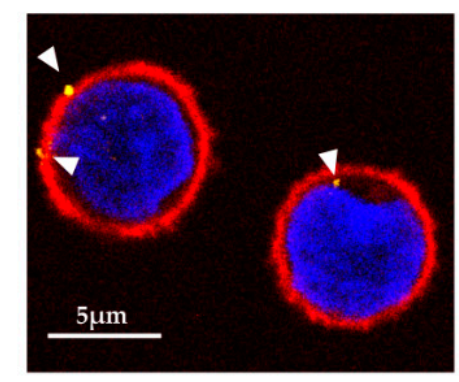

(d)

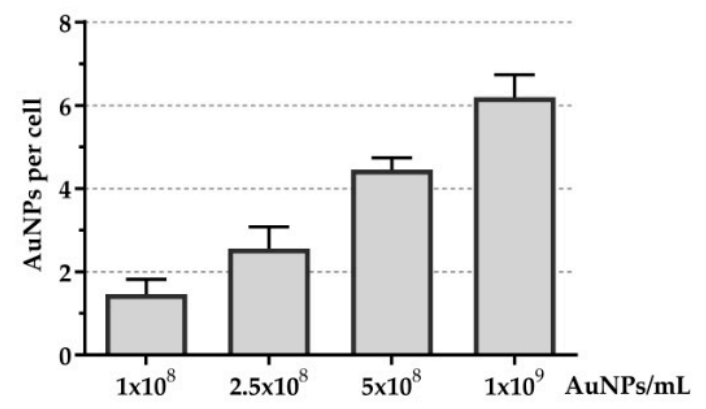

Figure 4. AuNP attachment to Jurkat $(\mathbf{a}, \mathbf{c})$ and primary human CD4+ T cells $(\mathbf{b}, \mathbf{d})$. Visualization of AuNPs attached to Jurkat (AuNP concentration: $8 \times 10^{7}$ AuNPs/mL) and primary T cells (AuNP concentration: $5 \times 10^{8}$ AuNPs/mL) by confocal reflection microscopy. AuNPs are color coded in yellow and indicated by white arrowheads. Cell membranes and nuclei are labeled with CellMask Deep Red stain (red) and Hoechst 33342 (blue), respectively (scale bar $=5 \mu \mathrm{m}$ ). Quantification of the average number of AuNPs attached to Jurkat (c) ( $n=3$ images, 160-220 cells/image) or primary human T cells (d) $(n=3$ images, $70-120$ cells/image) in a function of AuNP concentration.

\subsection{Intracellular Delivery of FITC-Dextran $10 \mathrm{kDa}$ into Jurkat Cells}

An initial experiment aimed to optimize the VNB photoporation procedure for the intracellular delivery of FD10 in Jurkat cells. The Jurkat human T cell line is commonly used as a model for hard-to-transfect primary human T cells. FITC-dextran with a molecular weight of $10 \mathrm{kDa}$ (FD10) was used as a model compound. The percentage of FD10-positive cells and cell viability were measured for three different AuNP concentrations (4, 8 and $\left.16 \times 10^{7} \mathrm{AuNPs} / \mathrm{ml}\right)$, corresponding to $\sim 1,2$, and 5 AuNPs per cell on average. As the AuNP concentration increases, so does the percentage of FD10-positive cells, as can be seen from the representative confocal microscopy images in Figure 5a and the quantitative flow cytometry data in Figure $5 \mathrm{~b}$. At the highest tested concentration of $16 \times 10^{7}$ AuNPs/mL, over $80 \%$ of FD10-positive Jurkat cells are obtained. The average amount of FD10 per cell 
also increases with AuNP concentration, which is here expressed as the relative mean fluorescence intensity (rMFI) compared to cells that were incubated with FD10 but without laser irradiation. Along with this increasing percentage of FD10-positive cells, a decreasing trend in cell viability was observed. To minimize cytotoxicity, an AuNP concentration of $4 \times 10^{7}$ AuNPs $/ \mathrm{mL}(\sim 1$ AuNP/cell) can be used for which $>60 \%$ of FD10-positive Jurkat cells are obtained with $>70 \%$ cell viability.

(a)

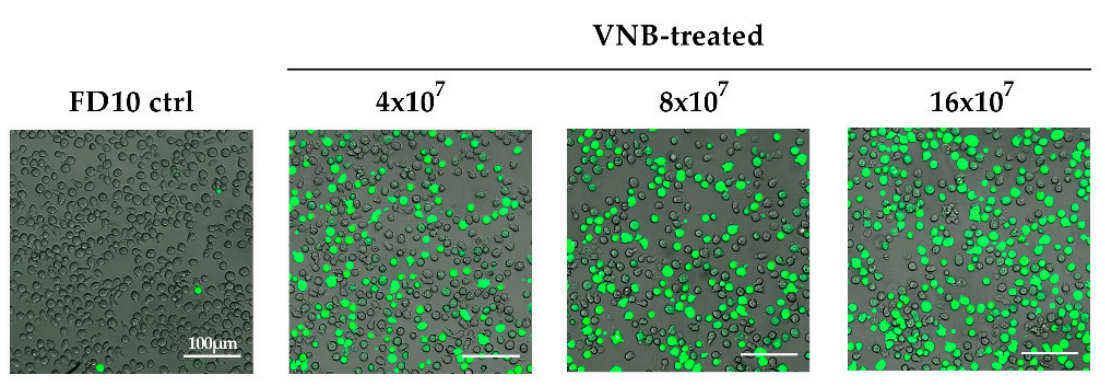

(b)

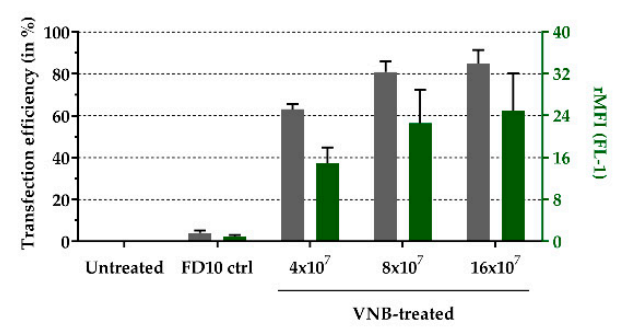

(c)

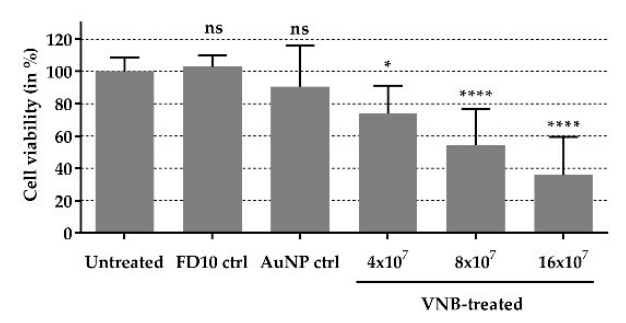

Figure 5. Intracellular delivery of $10 \mathrm{kDa}$ of FITC-dextran (FD10) in Jurkat cells by VNB photoporation. Jurkat cells were photoporated in the presence of FD10 after incubation with increasing concentrations of AuNPs, ranging from $4 \times 10^{7}$ to $16 \times 10^{7} \mathrm{AuNPs} / \mathrm{mL}$, and illumination with a single laser pulse of $1.9 \mathrm{~J} / \mathrm{cm}^{2}$. Untreated cells, cells incubated with FD10 (FD10 ctrl), or only incubated with AuNPs (AuNP ctrl) are used as controls. (a) Confocal microscopy images of Jurkat cells after photoporation in the presence of FD10 (scale bar $=100 \mu \mathrm{m})$. $(\mathbf{b})$ Graph representing the percentage of FD10-positive cells $\pm \mathrm{SD}$ and relative mean fluorescence intensity ( $\mathrm{rMFI}) \pm \mathrm{SD}(n=3$; independent repeats), measured by flow cytometry. (c) Graph representing the cell viability $\pm \mathrm{SD}(n=4$; independent repeats), as determined by a CellTiter-Glo ${ }^{\circledR}$ assay $2 \mathrm{~h}$ after laser irradiation. A one-way ANOVA with Dunnett's multiple comparison test was performed to determine statistical differences between the untreated sample and the other samples ( $n s=$ not significant, $\left.{ }^{*} p<0.05,{ }^{* * * *} p<0.0001\right)$.

\subsection{Intracellular Delivery of FITC-Dextran $10 \mathrm{kDa}$ into Primary Human CD4+ T Cells}

Encouraged by the promising results for Jurkat cells, we took the next step and investigated the applicability of VNB photoporation for the intracellular delivery of macromolecules in primary human CD4+ T cells. Again, we started by screening the percentage of FD10-positive cells and cytotoxicity for different AuNP concentrations. The quantification of AuNP attachment to CD4+ T cells (Figure 4d) already indicated that higher AuNP concentrations were required to have a similar number of AuNP adsorbed to the cells. Therefore, AuNP concentrations ranging from $1 \times 10^{8}$ to $1 \times 10^{9} \mathrm{AuNPs} / \mathrm{ml}$ were used for these photoporation experiments. Representative confocal images of photoporated cells are shown in Figure 6a, while quantitative flow cytometry results are shown in Figure 6b. As expected, an increasing percentage of FD10-positive cells was obtained for higher AuNP concentrations, with up to $80 \%$ FD10-positive cells for a concentration of $1 \times 10^{9} \mathrm{AuNPs} / \mathrm{ml}$. Of course, higher percentages of FD10-positive cells come at the expense of higher toxicity as well (Figure 6c). This is also why the number of green cells seems to decrease in the confocal images when the AuNP concentration exceeds $2.5 \times 10^{8} \mathrm{AuNP} / \mathrm{ml}$. At a concentration of $2.5 \times 10^{8} \mathrm{AuNPs} / \mathrm{ml}$, about $40 \%$ FD10-positive cells were obtained with an acceptable cell toxicity of $\sim 70 \%$. Taken together, these experiments clearly show that 
VNB photoporation can be successfully used to deliver $10 \mathrm{kDa}$ of dextran macromolecules in primary human CD4+ T-cells.

(a)

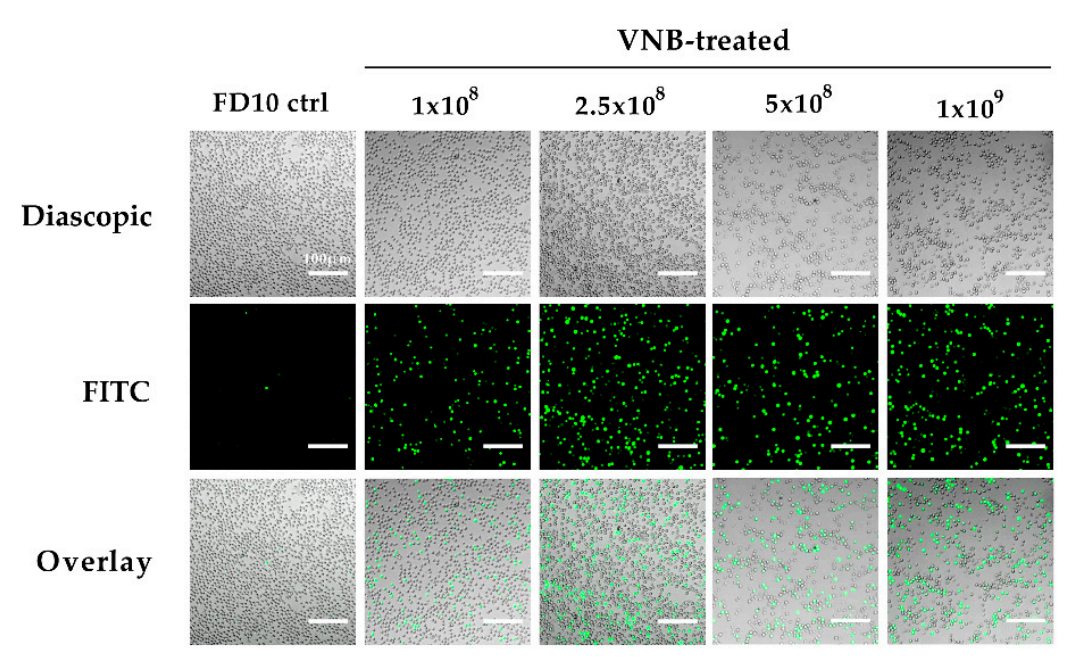

(b)

(c)
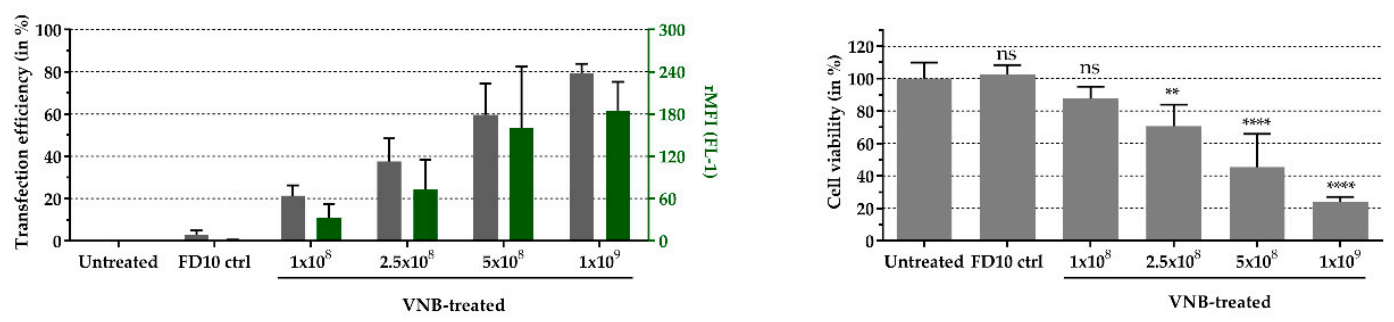

Figure 6. Intracellular delivery of $10 \mathrm{kDa}$ of FITC-dextran (FD10) in human CD4+ T cells by VNB photoporation. T cells were photoporated in the presence of FD10 after incubation with increasing concentrations of AuNPs, ranging from $1 \times 10^{8}$ to $1 \times 10^{9}$ AuNPs/mL, and irradiation with a laser fluence of $1.9 \mathrm{~J} / \mathrm{cm}^{2}$. Untreated cells, cells incubated with FD10 (FD10 ctrl), or cells incubated with AuNPs (AuNP ctrl) are used as controls. (a) Confocal microscopy images of T cells after photoporation in the presence of FD10 (scale bar $=100 \mu \mathrm{m}$ ). (b) Graph representing the percentage of FD10-positive cells \pm SD and relative mean fluorescence intensity (rMFI) $\pm \mathrm{SD}(n=2$; independent repeats), measured by flow cytometry. (c) Graph representing the cell viability \pm SD ( $n=2$; independent repeats) after $2 \mathrm{~h}$, as determined by a CellTiter-Glo ${ }^{\circledR}$ assay. A one-way ANOVA with Dunnett's multiple comparison test was performed to determine statistical differences between the untreated sample and the other samples (ns = not significant, ${ }^{* *} p<0.01,{ }^{* * * *} p<0.0001$ ).

\subsection{Intracellular Delivery of Higher Molecular Weight FITC-Dextrans into Jurkat Cells}

Above, we demonstrated the applicability of VNB photoporation for the efficient delivery of $10 \mathrm{kDa}$ FITC-dextrans in both Jurkat cells and primary human CD4+ T cells. To further assess the potency of the technique for the delivery of macromolecules even larger than $10 \mathrm{kDa}$, the delivery of FITC-dextrans with a molecular weight of $10 \mathrm{kDa}$ (FD10), $150 \mathrm{kDa}$ (FD150), and $500 \mathrm{kDa}$ (FD500) into Jurkat cells was evaluated. Using an AuNP concentration of $16 \times 10^{7} \mathrm{AuNPs} / \mathrm{mL}$ and a laser fluence of $1.9 \mathrm{~J} / \mathrm{cm}^{2}, 80 \%, 69 \%$, and 53\% FD-positive cells were obtained for FD10, FD150, and FD500, respectively (Figure $7 \mathrm{~b}$ ), indicating that the percentage of positive cells only moderately decreases with increasing FITC-dextran molecular weight. A more pronounced decrease is seen in the relative mean fluorescence intensity per cell (rMFI), as observed by both confocal microscopy images (Figure 7a) and quantitative flow cytometry data (Figure $7 \mathrm{~b}$ ). This is due to a combined effect of molecules becoming large compared to the pore size as well as slower molecular diffusion. 
(a)

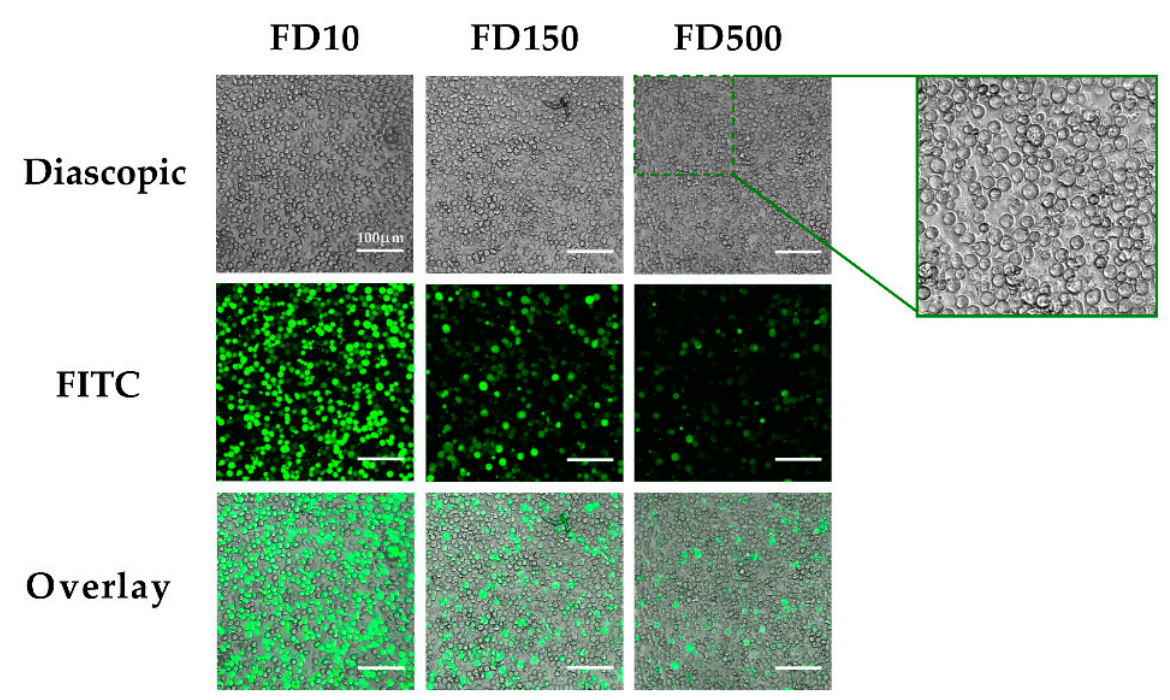

(b)

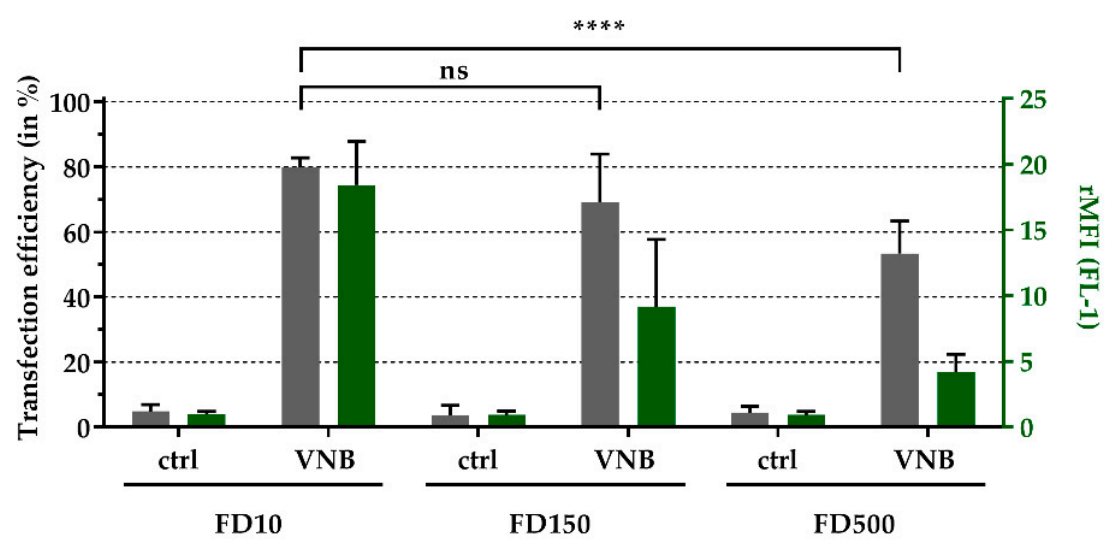

Figure 7. Intracellular delivery of FITC-dextrans (FD) of increasing molecular weight in Jurkat cells. FITC-dextrans with a molecular weight of 10 (FD10), 150 (FD150), or 500 kDa (FD500) were delivered by VNB photoporation, using an AuNP concentration of $16 \times 10^{7} \mathrm{AuNPs} / \mathrm{mL}$ and laser fluence of $1.9 \mathrm{~J} / \mathrm{cm}^{2}$. As controls, cells were incubated with the respective FITC-dextran without VNB treatment. (a) Confocal microscopy images of Jurkat cells photoporated in the presence of FD10, FD150, or FD500 (scale bar $=100 \mu \mathrm{m})$. (b) Graph representing the percentage of FD-positive cells \pm SD and relative mean fluorescence intensity (rMFI) $\pm \mathrm{SD}(n=2$; independent repeats), measured by flow cytometry. A two-tailed unpaired student's T test was performed to determine statistical differences $(n s=$ not significant, $\left.{ }^{* * * *} p<0.0001\right)$.

\section{Discussion}

The clinical success of adoptive T cell therapy, including the promising CAR T-cell therapies, strongly relies on the safe and efficacious engineering of $\mathrm{T}$ cells [2,41]. While viral vectors and electroporation are currently the preeminent transfection tools for $\mathrm{T}$ cells, these techniques are typically associated with several safety and cytotoxicity issues [15]. AuNP-sensitized VNB photoporation is an emerging approach for the safe and efficient intracellular delivery of macromolecules in a broad range of cell types $[31,34,35,42,43]$. Previously, our group and others already demonstrated the use of the technique for the delivery of macromolecules in murine CD8+ T cells $[35,44]$, but so far, the applicability for primary human CD4+ T cells remained elusive. In this study, we evaluated AuNP-sensitized VNB photoporation for the intracellular delivery of model macromolecules of increasing molecular weight in hard-to-transfect Jurkat and primary human CD4+ T cells.

VNB photoporation demands a combination of pulsed laser irradiation and light-absorbing nanoparticles (e.g., AuNPs) attached to the cell membrane. For this purpose, $60 \mathrm{~nm}$ AuNPs were 
synthetized in-house and modified with a cationic coating to enable efficient attachment to the negatively charged cell membrane. These AuNPs remained stable in cell culture medium, presumably due to the formation of a protein corona, which resulted in a slight increase in hydrodynamic radius [45,46]. The VNB generation threshold of the synthetized AuNPs was determined to be $0.96 \mathrm{~J} / \mathrm{cm}^{2}$, which is in good agreement with previously reported work on comparable AuNPs and with similar photoporation equipment [33-35].

Since the photoporation efficiency strongly depends on the ability of AuNPs to attach to the cell membrane, AuNP adsorption was visualized and quantified by confocal reflection microscopy. We found that after $30 \mathrm{~min}$ of incubation, the particles attached to the cell membrane surface without signs of internalization. This is to be expected, considering the impaired endocytic uptake in both Jurkat and primary $\mathrm{T}$ cells [35]. In addition, the quantification of AuNP attachment after AuNP incubation indicated that considerably higher AuNP concentrations were required for primary human CD4+ T cells $\left(10^{8}-10^{9} \mathrm{AuNPs} / \mathrm{ml}\right)$ as compared to Jurkat cells $\left(4-16 \times 10^{7} \mathrm{AuNPs} / \mathrm{ml}\right)$ to obtain a similar number of cell-attached AuNPs. The attachment of cationic nanoparticles to the cell membrane is enabled primarily by ionic interaction with negatively charged cell membrane proteoglycans, such as heparan sulfate proteoglycans (HSPGs) [47-51]. Quiescent primary human CD4+ T cells, as used in this study, typically have very low and even undetectable amounts of HSPGs [52], making the attachment of cationic AuNP less likely.

The human Jurkat suspension cell line is notoriously difficult-to-transfect and acts as a valid model for human primary T cell studies [53]. Therefore, the VNB photoporation procedure was first tested and optimized for macromolecular delivery in Jurkat cells using different AuNP concentrations. Fluorescent dextrans (FD) with a molecular weight of $10 \mathrm{kDa}$ served as a model compound, corresponding to the size of several therapeutic molecules, such as small nucleic acids (e.g., antisense oligonucleotides, siRNA/miRNA) or peptides. However, it should be noted that next to the physical size, also the shape, architecture, and physicochemical properties of a therapeutic cargo are very relevant characteristics to consider for intracellular delivery [15]. Increasing photoporation efficiencies were found for increasing AuNP concentrations, both in terms of the percentage of FD10-positive cells and the amount of dextran molecules that was delivered per cell. However, as is typical for any delivery technology, higher efficiencies were associated with higher cytotoxicity as well. At an AuNP concentration of $4 \times 10^{7}$ AuNPs/ml ( 1 AuNP/cell), a good balance was found between the percentage FD-positive cells ( $>60 \%)$ and cell viability $(>70 \%)$. These results are in line with previous work from our group on murine cytotoxic $T$ cells [35], and show that just a few AuNPs per cell are already sufficient to obtain efficient macromolecular delivery [54]. Following these promising results with $10 \mathrm{kDa}$ dextrans in Jurkat cells, VNB photoporation was further evaluated for the delivery of dextrans with a molecular weight of 150 and $500 \mathrm{kDa}$, corresponding to a hydrodynamic diameter of respectively $17 \mathrm{~nm}$ and $31 \mathrm{~nm}$. A wide range of therapeutically relevant cargoes are within this size range, including transcription factors, antibodies, and genome-editing nucleases [15]. Our results are in agreement with a previous study from our group on HeLa cells [55], and suggested that the VNB-induced pores can have a size of up to $30 \mathrm{~nm}$, as inferred by the observed influx of $500 \mathrm{kDa}$ dextrans. For the efficient delivery of cargoes of this size, the generated membrane pores should be big enough and remain open sufficiently long for these larger and slowly diffusing molecules to be able to reach the cell cytoplasm. In this regard, the observed decrease in relative fluorescence per cell, but high percentage of positive cells, for higher molecular weight dextrans is understandable.

While human CD4+ T cells are well-known for their central role in antiviral immune responses, it is becoming clear that these 'helper' $\mathrm{T}$ cells are also required for the generation of an efficacious antitumor environment in therapeutic cell therapy [5,7]. Indeed, they have been shown to increase the potency of in vivo adoptive $\mathrm{T}$ cell therapy [56-58]. Therefore, human CD4+ T cells serve as very relevant and interesting targets for therapeutic cell engineering. Unfortunately, quiescent primary human $\mathrm{CD} 4+\mathrm{T}$ cells are notoriously hard-to-transfect and are resistant to many different conventional polymer-based and lipid-based transfection modalities [15]. By VNB photoporation, we successfully 
delivered $10 \mathrm{kDa}$ dextrans in CD4+ T cells. The percentage FD10-positive cells again increased with increasing AuNP concentration at the expense of decreasing cell viability. Still, 40\% FD10-positive cells could be obtained with a high level of cell viability $(>70 \%)$. However, it should be noted that future research on the transfection of functional macromolecules (e.g., siRNA or mRNA) should take into account the specific T-cell subtype [59] and activation state [56,60], as it can strongly influence the transfection outcome.

Altogether, our findings here demonstrate the applicability of VNB photoporation for the safe and efficient intracellular delivery of model macromolecules in Jurkat and human CD4+ T cells. Primary human $\mathrm{T}$ cells, especially quiescent $\mathrm{T}$ cells, are considered hard-to-transfect with most of the currently available transfection methods. The successful delivery of fluorescent dextrans of up to $500 \mathrm{kDa}$ by VNB photoporation, as demonstrated here, paves the way for future research on the use of the technology for transfection of human CD4+ T cells with functional macromolecules, such as CAR-T mRNA for adoptive T-cell therapy [3], CRISPR ribonucleoprotein complexes for CCR5 knock out, or antibodies for CD4 protein knockdown [61].

Author Contributions: Conceptualization, L.R., S.S., K.R. and K.B.; Investigation, L.R., C.V.H. and J.M.; Project administration, L.R., S.S., K.R. and K.B.; Resources, J.C.F., T.B. and R.X.; Supervision, S.S., S.D.S., L.V., K.R. and K.B.; Writing—original draft, L.R.; Writing—review \& editing, L.R., C.V.H., J.M., S.S., J.C.F., T.B., R.X., S.D.S., L.V., K.R. and K.B.

Funding: This research was funded by the European Research Council (ERC) under the European Union's Horizon 2020 research and innovation program (Grant No. 648124). C.V.H. is funded by the Research Foundation Flanders (FWO), Belgium (FWO-SB grant no. 1S30816N). L.V. acknowledges the support of the FWO fundamental clinical mandate (grant no. 1.8.020.09.N.00). S.S. is funded by the VLAIO grant (HBC.2017.0542.).

Conflicts of Interest: The authors declare no conflict of interest.

\section{References}

1. June, C.H.; Levine, B.L. T cell engineering as therapy for cancer and HIV: Our synthetic future. Philos. Trans. R. Soc. B Biol. Sci. 2015, 370, 20140374. [CrossRef] [PubMed]

2. Sadelain, M.; Rivière, I.; Riddell, S. Therapeutic T cell engineering. Nature 2017, 545, 423-431. [CrossRef] [PubMed]

3. Fesnak, A.D.; June, C.H.; Levine, B.L. Engineered T cells: The promise and challenges of cancer immunotherapy. Nat. Rev. Cancer 2016, 16, 566-581. [CrossRef] [PubMed]

4. Hale, M.; Mesojednik, T.; Romano Ibarra, G.S.; Sahni, J.; Bernard, A.; Sommer, K.; Scharenberg, A.M.; Rawlings, D.J.; Wagner, T.A. Engineering HIV-Resistant, Anti-HIV Chimeric Antigen Receptor T Cells. Mol. Ther. 2017, 25, 570-579. [CrossRef] [PubMed]

5. Borst, J.; Ahrends, T.; Bąbała, N.; Melief, C.J.M.; Kastenmüller, W. CD4+ T cell help in cancer immunology and immunotherapy. Nat. Rev. Immunol. 2018, 18, 635-647. [CrossRef] [PubMed]

6. Kennedy, R.; Celis, E. Multiple roles for CD4+ T cells in anti-tumor immune responses. Immunol. Rev. 2008, 222, 129-144. [CrossRef]

7. Kamphorst, A.O.; Ahmed, R. CD4 T-cell immunotherapy for chronic viral infections and cancer. Immunotherapy 2013, 5, 975-987. [CrossRef] [PubMed]

8. Autologous T-Cells Genetically Modified at the CCR5 Gene by Zinc Finger Nucleases SB-728 for HIV - Full Text View - ClinicalTrials.gov. Available online: https://clinicaltrials.gov/ct2/show/NCT00842634 (accessed on 23 April 2019).

9. Phase 1 Dose Escalation Study of Autologous T-cells Genetically Modified at the CCR5 Gene by Zinc Finger Nucleases in HIV-Infected Patients - Full Text View - ClinicalTrials.gov. Available online: https: //clinicaltrials.gov/ct2/show/NCT01044654 (accessed on 23 April 2019).

10. Study of Autologous T-cells Genetically Modified at the CCR5 Gene by Zinc Finger Nucleases in HIV-Infected Subjects - Full Text View - ClinicalTrials.gov. Available online: https://clinicaltrials.gov/ ct2/show/NCT01252641 (accessed on 23 April 2019).

11. Varela-Rohena, A.; Carpenito, C.; Perez, E.E.; Richardson, M.; Parry, R.V.; Milone, M.; Scholler, J.; Hao, X.; Mexas, A.; Carroll, R.G.; et al. Genetic engineering of T cells for adoptive immunotherapy. Immunol. Res. 2008, 42, 166-181. [CrossRef] 
12. Hultquist, J.F.; Hiatt, J.; Schumann, K.; McGregor, M.J.; Roth, T.L.; Haas, P.; Doudna, J.A.; Marson, A.; Krogan, N.J. CRISPR-Cas9 genome engineering of primary CD4 + T cells for the interrogation of HIV-host factor interactions. Nat. Protoc. 2019, 14, 1. [CrossRef]

13. Leibman, R.S.; Riley, J.L. Engineering T Cells to Functionally Cure HIV-1 Infection. Mol. Ther. 2015, 23, 1149-1159. [CrossRef]

14. Peer, D. A daunting task: Manipulating leukocyte function with RNAi. Immunol. Rev. 2013, 253, $185-197$. [CrossRef]

15. Stewart, M.P.; Langer, R.; Jensen, K.F. Intracellular Delivery by Membrane Disruption: Mechanisms, Strategies, and Concepts. Chem. Rev. 2018, 118, 7409-7531. [CrossRef]

16. Granot-Matok, Y.; Kon, E.; Dammes, N.; Mechtinger, G.; Peer, D. Therapeutic mRNA delivery to leukocytes. J. Control. Release Off. J. Control. Release Soc. 2019, 305, 165-175. [CrossRef]

17. Yin, H.; Kanasty, R.L.; Eltoukhy, A.A.; Vegas, A.J.; Dorkin, J.R.; Anderson, D.G. Non-viral vectors for gene-based therapy. Nat. Rev. Genet. 2014, 15, 541-555. [CrossRef]

18. Roth, T.L.; Puig-Saus, C.; Yu, R.; Shifrut, E.; Carnevale, J.; Li, P.J.; Hiatt, J.; Saco, J.; Krystofinski, P.; Li, H.; et al. Reprogramming human $\mathrm{T}$ cell function and specificity with non-viral genome targeting. Nature 2018, 559, 405. [CrossRef]

19. Sahay, G.; Querbes, W.; Alabi, C.; Eltoukhy, A.; Sarkar, S.; Zurenko, C.; Karagiannis, E.; Love, K.; Chen, D.; Zoncu, R.; et al. Efficiency of siRNA delivery by lipid nanoparticles is limited by endocytic recycling. Nat. Biotechnol. 2013, 31, 653-658. [CrossRef]

20. Vermeulen, L.M.P.; Brans, T.; Samal, S.K.; Dubruel, P.; Demeester, J.; Smedt, S.C.D.; Remaut, K.; Braeckmans, K. Endosomal Size and Membrane Leakiness Influence Proton Sponge-Based Rupture of Endosomal Vesicles. ACS Nano 2018, 12, 2332-2345. [CrossRef]

21. Schaffer, D.V.; Fidelman, N.A.; Dan, N.; Lauffenburger, D.A. Vector unpacking as a potential barrier for receptor-mediated polyplex gene delivery. Biotechnol. Bioeng. 2000, 67, 598-606. [CrossRef]

22. Stewart, M.P.; Sharei, A.; Ding, X.; Sahay, G.; Langer, R.; Jensen, K.F. In vitro and ex vivo strategies for intracellular delivery. Nature 2016, 538, 183-192. [CrossRef]

23. Shi, J.; Ma, Y.; Zhu, J.; Chen, Y.; Sun, Y.; Yao, Y.; Yang, Z.; Xie, J. A Review on Electroporation-Based Intracellular Delivery. Molecules 2018, 23, 3044. [CrossRef]

24. Venslauskas, M.S.; Šatkauskas, S. Mechanisms of transfer of bioactive molecules through the cell membrane by electroporation. Eur. Biophys. J. 2015, 44, 277-289. [CrossRef]

25. DiTommaso, T.; Cole, J.M.; Cassereau, L.; Buggé, J.A.; Hanson, J.L.S.; Bridgen, D.T.; Stokes, B.D.; Loughhead, S.M.; Beutel, B.A.; Gilbert, J.B.; et al. Cell engineering with microfluidic squeezing preserves functionality of primary immune cells in vivo. Proc. Natl. Acad. Sci. 2018, 115, E10907-E10914. [CrossRef]

26. Zhang, M.; Ma, Z.; Selliah, N.; Weiss, G.; Genin, A.; Finkel, T.H.; Cron, R.Q. The impact of Nucleofection ${ }^{\circledR}$ on the activation state of primary human CD4 T cells. J. Immunol. Methods 2014, 408, 123-131. [CrossRef]

27. Sharei, A.; Zoldan, J.; Adamo, A.; Sim, W.Y.; Cho, N.; Jackson, E.; Mao, S.; Schneider, S.; Han, M.-J.; Lytton-Jean, A.; et al. A vector-free microfluidic platform for intracellular delivery. Proc. Natl. Acad. Sci. 2013, 110, 2082-2087. [CrossRef]

28. Sharei, A.; Trifonova, R.; Jhunjhunwala, S.; Hartoularos, G.C.; Eyerman, A.T.; Lytton-Jean, A.; Angin, M.; Sharma, S.; Poceviciute, R.; Mao, S.; et al. Ex Vivo Cytosolic Delivery of Functional Macromolecules to Immune Cells. PLoS ONE 2015, 10, e0118803. [CrossRef]

29. Qin, Z.; Bischof, J.C. Thermophysical and biological responses of gold nanoparticle laser heating. Chem. Soc. Rev. 2012, 41, 1191-1217. [CrossRef]

30. Komiyama, M.; Yoshimoto, K.; Sisido, M.; Ariga, K. Chemistry Can Make Strict and Fuzzy Controls for Bio-Systems: DNA Nanoarchitectonics and Cell-Macromolecular Nanoarchitectonics. Bull. Chem. Soc. Jpn. 2017, 90, 967-1004. [CrossRef]

31. Xiong, R.; Samal, S.K.; Demeester, J.; Skirtach, A.G.; Smedt, S.C.D.; Braeckmans, K. Laser-assisted photoporation: Fundamentals, technological advances and applications. Adv. Phys. X 2016, 1, 596-620. [CrossRef]

32. Lukianova-Hleb, E.; Hu, Y.; Latterini, L.; Tarpani, L.; Lee, S.; Drezek, R.A.; Hafner, J.H.; Lapotko, D.O. Plasmonic Nanobubbles as Transient Vapor Nanobubbles Generated Around Plasmonic Nanoparticles. ACS Nano 2010, 4, 2109-2123. [CrossRef] 
33. Lapotko, D. Optical excitation and detection of vapor bubbles around plasmonic nanoparticles. Opt. Express 2009, 17, 2538-2556. [CrossRef]

34. Xiong, R.; Raemdonck, K.; Peynshaert, K.; Lentacker, I.; De Cock, I.; Demeester, J.; De Smedt, S.C.; Skirtach, A.G.; Braeckmans, K. Comparison of gold nanoparticle mediated photoporation: Vapor nanobubbles outperform direct heating for delivering macromolecules in live cells. ACS Nano 2014, 8, 6288-6296. [CrossRef]

35. Wayteck, L.; Xiong, R.; Braeckmans, K.; De Smedt, S.C.; Raemdonck, K. Comparing photoporation and nucleofection for delivery of small interfering RNA to cytotoxic T cells. J. Control. Release Off. J. Control. Release Soc. 2017, 267, 154-162. [CrossRef]

36. Turkevich, J.; Stevenson, P.C.; Hillier, J. A study of the nucleation and growth processes in the synthesis of colloidal gold. Discuss. Faraday Soc. 1951, 11, 55-75. [CrossRef]

37. Vermeulen, L.M.P.; Fraire, J.C.; Raes, L.; De Meester, E.; De Keulenaer, S.; Van Nieuwerburgh, F.; De Smedt, S.; Remaut, K.; Braeckmans, K. Photothermally Triggered Endosomal Escape and Its Influence on Transfection Efficiency of Gold-Functionalized JetPEI/pDNA Nanoparticles. Int. J. Mol. Sci. 2018, 19, 2400. [CrossRef]

38. Haiss, W.; Thanh, N.T.K.; Aveyard, J.; Fernig, D.G. Determination of Size and Concentration of Gold Nanoparticles from UV-Vis Spectra. Anal. Chem. 2007, 79, 4215-4221. [CrossRef]

39. Xu, Y.; Gustafson, B.Å.S. A generalized multiparticle Mie-solution: Further experimental verification. J. Quant. Spectrosc. Radiat. Transf. 2001, 70, 395-419. [CrossRef]

40. González-Rubio, G.; Guerrero-Martínez, A.; Liz-Marzán, L.M. Reshaping, Fragmentation, and Assembly of Gold Nanoparticles Assisted by Pulse Lasers. Acc. Chem. Res. 2016, 49, 678-686. [CrossRef]

41. Labanieh, L.; Majzner, R.G.; Mackall, C.L. Programming CAR-T cells to kill cancer. Nat. Biomed. Eng. 2018, 2, 377. [CrossRef]

42. Xiong, R.; Drullion, C.; Verstraelen, P.; Demeester, J.; Skirtach, A.G.; Abbadie, C.; De Vos, W.H.; De Smedt, S.C.; Braeckmans, K. Fast spatial-selective delivery into live cells. J. Control. Release 2017, 266, 198-204. [CrossRef]

43. Xiong, R.; Verstraelen, P.; Demeester, J.; Skirtach, A.G.; Timmermans, J.-P.; De Smedt, S.C.; De Vos, W.H.; Braeckmans, K. Selective Labeling of Individual Neurons in Dense Cultured Networks With Nanoparticle-Enhanced Photoporation. Front. Cell. Neurosci. 2018, 12, 80. [CrossRef]

44. Bošnjak, B.; Permanyer, M.; Sethi, M.K.; Galla, M.; Maetzig, T.; Heinemann, D.; Willenzon, S.; Förster, R.; Heisterkamp, A.; Kalies, S. CRISPR/Cas9 Genome Editing Using Gold-Nanoparticle-Mediated Laserporation. Adv. Biosyst. 2018, 2, 1700184. [CrossRef]

45. Gebauer, J.S.; Malissek, M.; Simon, S.; Knauer, S.K.; Maskos, M.; Stauber, R.H.; Peukert, W.; Treuel, L. Impact of the Nanoparticle-Protein Corona on Colloidal Stability and Protein Structure. Langmuir 2012, 28, 9673-9679. [CrossRef]

46. Charbgoo, F.; Nejabat, M.; Abnous, K.; Soltani, F.; Taghdisi, S.M.; Alibolandi, M.; Thomas Shier, W.; Steele, T.W.J.; Ramezani, M. Gold nanoparticle should understand protein corona for being a clinical nanomaterial. J. Controlled Release 2018, 272,39-53. [CrossRef]

47. Mislick, K.A.; Baldeschwieler, J.D. Evidence for the role of proteoglycans in cation-mediated gene transfer. Proc. Natl. Acad. Sci. 1996, 93, 12349. [CrossRef]

48. Riedl, S.A.B.; Kaiser, P.; Raup, A.; Synatschke, C.V.; Jérôme, V.; Freitag, R. Non-Viral Transfection of Human T Lymphocytes. Processes 2018, 6, 188. [CrossRef]

49. Zarska, M.; Novotny, F.; Havel, F.; Sramek, M.; Babelova, A.; Benada, O.; Novotny, M.; Saran, H.; Kuca, K.; Musilek, K.; et al. Two-Step Mechanism of Cellular Uptake of Cationic Gold Nanoparticles Modified by (16-Mercaptohexadecyl) trimethylammonium Bromide. Bioconjug. Chem. 2016, 27, 2558-2574. [CrossRef]

50. Fadnes, B.; Husebekk, A.; Svineng, G.; Rekdal, Ø.; Yanagishita, M.; Kolset, S.O.; Uhlin-Hansen, L. The proteoglycan repertoire of lymphoid cells. Glycoconj. J. 2012, 29, 513-523. [CrossRef]

51. Olden, B.R.; Cheng, Y.; Yu, J.L.; Pun, S.H. Cationic polymers for non-viral gene delivery to human T cells. J. Control. Release 2018, 282, 140-147. [CrossRef]

52. Jones, K.S.; Petrow-Sadowski, C.; Bertolette, D.C.; Huang, Y.; Ruscetti, F.W. Heparan Sulfate Proteoglycans Mediate Attachment and Entry of Human T-Cell Leukemia Virus Type 1 Virions into CD4+ T Cells. J. Virol. 2005, 79, 12692-12702. [CrossRef]

53. Abraham, R.T.; Weiss, A. Jurkat T cells and development of the T-cell receptor signalling paradigm. Nat. Rev. Immunol. 2004, 4, 301-308. [CrossRef] 
54. Heinemann, D.; Schomaker, M.; Kalies, S.; Schieck, M.; Carlson, R.; Escobar, H.M.; Ripken, T.; Meyer, H.; Heisterkamp, A. Gold Nanoparticle Mediated Laser Transfection for Efficient siRNA Mediated Gene Knock Down. PLOS ONE 2013, 8, e58604. [CrossRef]

55. Xiong, R.; Joris, F.; Liang, S.; De Rycke, R.; Lippens, S.; Demeester, J.; Skirtach, A.; Raemdonck, K.; Himmelreich, U.; De Smedt, S.C.; et al. Cytosolic Delivery of Nanolabels Prevents Their Asymmetric Inheritance and Enables Extended Quantitative in Vivo Cell Imaging. Nano Lett. 2016, 16, 5975-5986. [CrossRef]

56. Zhang, Z.; Qiu, S.; Zhang, X.; Chen, W. Optimized DNA electroporation for primary human T cell engineering. BMC Biotechnol. 2018, 18, 4. [CrossRef]

57. Singh, N.; Perazzelli, J.; Grupp, S.A.; Barrett, D.M. Early memory phenotypes drive T cell proliferation in patients with pediatric malignancies. Sci. Transl. Med. 2016, 8, 320ra3. [CrossRef]

58. Sommermeyer, D.; Hudecek, M.; Kosasih, P.L.; Gogishvili, T.; Maloney, D.G.; Turtle, C.J.; Riddell, S.R. Chimeric antigen receptor-modified $\mathrm{T}$ cells derived from defined $\mathrm{CD} 8^{+}$and $\mathrm{CD} 4^{+}$subsets confer superior antitumor reactivity in vivo. Leukemia 2016, 30, 492-500. [CrossRef]

59. Sun, B.; Zhang, Y. Overview of orchestration of CD4+ T cell subsets in immune responses. Adv. Exp. Med. Biol. 2014, 841, 1-13.

60. McManus, M.T.; Haines, B.B.; Dillon, C.P.; Whitehurst, C.E.; van Parijs, L.; Chen, J.; Sharp, P.A. Small Interfering RNA-Mediated Gene Silencing in T Lymphocytes. J. Immunol. 2002, 169, 5754-5760. [CrossRef]

61. Clift, D.; McEwan, W.A.; Labzin, L.I.; Konieczny, V.; Mogessie, B.; James, L.C.; Schuh, M. A Method for the Acute and Rapid Degradation of Endogenous Proteins. Cell 2017, 171, 1692-1706. [CrossRef]

(C) 2019 by the authors. Licensee MDPI, Basel, Switzerland. This article is an open access article distributed under the terms and conditions of the Creative Commons Attribution (CC BY) license (http://creativecommons.org/licenses/by/4.0/). 